\title{
CORRESPONDENCE
}

\section{Tanks and tactics}

SIR - Allied military command will doubtless hope that enemy tank designers take John Baruch's advice (Nature 27 August, p.792) and add an extra 5 tons of shielding to each 30 -ton tank. This would increase the cost of transport of enemy tanks by $(5 / 30) \times 100=17$ per cent. Meaning either they would have 17 per cent less acceleration (so would be easier to hit with conventional rockets) or, if their acceleration performance were retained, would require 17 per cent more fuel and have drive and weightbearing parts 17 per cent stronger, further adding to their weight.

Though never even primed, the neutron bomb would serve its purpose by making enemy tanks ungainly and more vulnerable to conventional weapons.

Oliver Milburn

\section{Leeds, Yorkshire, UK}

SIR - I was very disturbed by your leading article (Nature 13 August, p.571) favouring the neutron bomb, designed to be an anti-tank weapon, killing tank crews within a 1,500 -foot radius while minimizing property damage. The countermeasure is simple: the Russians need only attack in loose formations maintaining a distance greater than 1,500 feet between tanks.

Tanks are best suited to warfare in open country where there is little property to destroy. Tanks used in built-up areas are vulnerable to weapons much less sophisticated than neutron bombs - such as Molotov cocktails, as the Russians themselves proved, to the Nazis' chagrin, in the battle of Stalingrad. And anyway such built-up areas are likely to contain large numbers of Western European civilians who are no less vulnerable to high-intensity neutron radiation than are Russian tank crews.

Robert J. YAes Memorial Sloan-Kettering Cancer Center, New York, USA

\section{Toxic edible oils}

SIR - We read with interest the account by Hilton and Gillman in the Sunday Times (23 August 1981) describing the tragic outcome of the use in Spain of industrial oil in place of edible olive oil. The industrial oil was based on low euric acid rape seed oil plus grape and cotton seed oils, all of which contain high levels of unsaturated fatty acids.

There are many diseases in farm animals which can be regarded as being induced directly by the degradation of normal dietary intakes of unsaturated fatty acids. This is especially so if the natural antioxidants vitamin $E$ and selenium are present in insufficient quantities, in tissue, to interrupt the process of peroxidative damage. The tissues most usually affected are muscle, heart, liver and brain.

Nutritional degenerative myopathy (NMD) can occur when young ruminants deficient in vitamin $E$ and selenium are turned out to young grass which is normally high in unsaturated fatty acids $s^{l}$. When such animals consume this material the unsaturated fatty acids largely escape conversion to saturated fatty acids (hydrogenation) in the rumen and are absorbed ${ }^{2}$. That this is the source of unsaturated fatty acids for lipid peroxidation has been recently confirmed experimentally ${ }^{3}$.
Animals with a normal status of vitamin $\mathrm{E}$ and selenium are not affected, showing that these micronutrients are essential in protecting against peroxidative damage.

What makes these studies particularly relevant is first that disease is induced by feeding unsaturated fatty acid. Second, many of the symptoms seen in calves affected with the peroxidative disease (NMD) are very similar to those described in the people affected in Spain - symptoms of respiratory distress, muscle weakness and pain, along with an inability to rise. Changes also occurred to teeth and skin. Deaths have also been attributed to consumption of the oil.

The oil used in Spain, as well as being rich in unsaturated fatty acids, had been heat treated to $200^{\circ} \mathrm{C}$ to make it acceptable. Heat treatment of unsaturated fatty acids can induce peroxidative damage with the formation of toxic hydroperoxides, and destroy vitamin E. Indeed Spanish physicians found vitamin $E$ to be the most appropriate treatment for the disease.

Both the recent Spanish experience and our own experiments highlight the necessity of ensuring that unsaturated fatty acids are used correctly. Molecular damage resulting from peroxidative pathways can result in alteration in lipids (membranes), proteins (enzyme activity) and nucleic acids ${ }^{4}$. This gives considerable potential for both short and long term pathogenic processes. Thus where the consumption of unsaturated fatty acids occurs and especially where their use is actively encouraged, care must be exercised to ensure that tissue peroxidation is not an extremely unpleasant sequel. Vitamin $\mathrm{E}$ and selenium dietary intake levels must be adequate to ensure that this is not the case.

\section{H. MCMurraY}

\section{A. RICE}

Veterinary Research Laboratories,

Stormont, Belfast, UK

1. McMurray, C.H. \& McEldowny, K. Br. Vet. J. 133, $535-542$ (1977).

2. McMurray, C.H., Rice, D.A. \& Blanchflower, J. Proc. nutr. Soc. 39, 65A (1980).

3. Rice, D.A., Blanchflower, J. \& McMurray, C.H. Vet. Rec. 109, 161-162 (1981)

4. Tappel, A.L. in Free Radicles in Biology Vol. 4, (ed. Pyror, W.R.) 1-47 (Academic, New York, 1980).

\section{Those specimens}

SiR - For readers of Nature of 3 September (p.6) Brian Ford has readily blamed staff of this journal for a particular sentence (and the title?) of his article (Nature 30 July, p.407) reporting on 'Leeuwenhoek's specimens discovered after 307 years". But his tightly literal answer is hardly impressive when it is compared with his concurrent article, and allied response regarding earlier knowledge of Leeuwenhoek's specimens, in New Scientist

(30 July, p.301; 3 September, p.619).

I am particularly surprised when he dismisses Clifford Dobell's fine standard book on Leeuwenhoek (1932 and 1960) and Professor Cole's work of the 1930s as merely that of "occasional individuals half a century ago". Oddly, he now says the statement about the existence of Leeuwenhoek's specimens made on p.333 of Dobell's book is referred to in his own main article in Notes and Records of the Royal Society. This will be a welcome variation on the available accounts in Nature and New Scientist, but it is difficult to adjust existing criticism at the time of writing this letter because publication of the Notes and Records cited by him has been delayed until at least the end of September.

$\mathrm{Mr}$ Ford is right to be enthusiastic over his examination of Leeuwenhoek's original specimens with a scanning electron microscope (ideally suitable for unfixed dried biological material), but he only has himself to blame in turning attention away from this main theme.

Bromley, Kent, UK

R. Derek Wood

\section{Balance of powers}

SIR - I do understand why Dr Jeffery (Nature 27 August, p.791) should have used the retail price index to correct for inflation in the calculation of relative energy costs, except insofar as it mirrors the wholesale price index. One hardly buys power stations retail. Neither do I know of any investment giving a steady return of 5 per cent above inflation rate.

At the same time I accept that there is an uncertainty about the effective total cost of either coal or nuclear energy which may well be comparable with the difference between the figures given by Dr Jeffery and those given by the Central Electricity Generating Board (CEGB). Neither party would get much credit in an examination for quoting figures to better than 1 per cent without any estimate of probable error.

But the importance of the controversy lies in its relevance to future action. Power stations started in the next few years will be in the middle of their working lives in about 25 years' time, and "guesstimates" as to the cost ratio at that time are so uncertain that the differences between Dr Jeffery's figures and those of the CEGB are quite negligible. Nearly all the likely changes favour building more nuclear power stations. The cost of oil is likely to be so high that it will be more expensive for transport than synthetic liquid fuel so more coal may be needed to produce this than is at present used for all purposes. Concurrently, electric transport at least for buses and heavy lorries may increase the total demand for electricity, requiring more electric power than at present, even though current "guesstimates" neglecting this possibility suggest that we shall need less.

We ought to be offering the Third World cheap coal now, instead of lecturing them on the undesirability of burning down their forests for fuel, but surely by the year 2005 the Third World demand for mass-produced consumer goods will be relatively less and its demand for energy more, so that our most valuable exports could be coal, windgenerators and solar electric plants - if we have any to spare.

Finally, if the charges on capital should increase by a further large proportion, which increases the relative cost of nuclear electricity, this will discriminate still more heavily against the solar, tidal, wind and wave alternatives, almost the whole of the costs of these being charges on capital, so that nuclear power may still be the cheapest way of making up whatever cannot be supplied by coal. As of now it is the only means capable of the scale of output needed. JOHN FREMLIN

Department of Physics,

University of Birmingham, $U K$ 